\title{
Conflicting Versions of Tragic Socrates-A Victim of Democracy or Anti-Democracy?
}

\author{
Heba H. El-ABBADI \\ Cairo University
}

The aim of this paper is to investigate three dramatic presentations that treat the events of the trial and death of Socrates. With reference to Cultural Materialism, intertextuality, and to three tragic theories, the paper will show how the controversial character of Socrates is treated diversely through the ages in different societies. The paper first examines Plato's The Trial and Death of Socrates, which includes Euthyphro (c. 399 B.C), Apology (399 B.C), Crito (360 B.C.) and Phaedo (360 B.C), as a tragic tetralogy written during the heyday of Greek Democracy, with special reference to Aristotle's Poetics (335 B.C.). Furthermore, it explores the cultural and political factors that led two modern dramatists to adapt Plato's dialogues in their respective plays, namely, the British playwright Clifford Bax's Socrates (1930) in connection to George Steiner's The Death of Tragedy (1961), and the American dramatist Maxwell Anderson's Barefoot in Athens (1951) against his tragic theory formulated in 'The Essence of Tragedy' (1931).

Initiated in the 1970s in Britain and redefined in the 1980s, cultural materialism "stresses interaction between cultural creations such as literature and their historical context, including social, political and economic elements" (Nostbakken 2000, 21-25, esp. 21). The cultural materialist thus seeks "to expose the political unconscious of the text" (Sinfield 2006, 25+). Jonathan Dollimore and Alan Sinfield refer to the meaning of the term they promoted in their Political Shakespeare: Essays in Cultural Materialism (1985) as "a combination of historical context, theoretical method, political commitment and contextual analysis" (1985, vii). They elaborate:

Classical Papers, vol. xi , 2012 


\section{Conflicting Versions of Tragic Socrates}

Historical context undermines the transcendent significance traditionally accorded to the literary text and allows us to recover its histories; theoretical method detaches the text from immanent criticism which seeks only to reproduce it in its own terms; . . . textual analysis locates the critique of traditional approaches where it cannot be ignored. (vii)

Intertextuality "implies that all creation is social creation, all production always reproduction: everything we think, say, or do relies upon ideas, words, and cultural norms that pre-exist us" (Fishlin and Fortier 2000, 4). Julia Kristeva developed the concepts of intertextuality in 1969 to signify "the multiple ways in which any one literary text is in fact made up of other texts, by means of its open or covert citations and allusions, its repetitions and transformations of the formal and substantive features of earlier texts" (Abrams and Harpham 2009, 364). Kristeva goes a step further because for her intertextuality "situates the text within history and society, which are seen as texts read by the writer, and into which he inserts himself by rewriting them" (Kristeva 1980, 67).

Thus, by having recourse to both cultural materialism and intertextuality, the paper will show how Socrates' tragedy has stimulated modern Western playwrights to express their concerns for their contemporary societies. The two modern plays under study are two intertexts that allow their audiences to relate to contemporary social and political issues.

Socrates, the most influential philosopher of the Western world, is known for what is called today the "Socratic Method." Though he has left no legacy in the form of the written word, Socrates was made famous through the works of his pupils, namely, Plato's Socratic Dialogues and Xenophone's Socratic works Memorabilia of Socrates and Apologia Sōcratous. They display his method where he would ask a series of questions, the answers of which would lead his interlocutor to ultimate truth. Socrates' method was caricatured by Aristophanes in his comedy Clouds. Aristophanes' criticism was directed at the sophists, but he 


\section{Heba H. El-ABBADI}

portrayed the personage of Socrates as their representative, thus drawing an amoral character who aims to destroy traditional religious and ethical beliefs and who promotes in its stead deceptive reasoning. Clouds is of particular significance because the charges brought against Socrates in 399 B.C. were identical to Aristophanes' accusations. Jurors who watched Aristophanes' play were influenced by it. Indeed, he was arrested under the charge of corrupting the youth, and for allegedly promoting gods of his own creativity instead of the known established gods. He stood trial and was finally convicted to face the death sentence by drinking hemlock.

It is worth mentioning that as Thomas C. Brickhouse explains, "the government of Athens in Socrates' time was a constitutional democracy whose principal governing body was the popular Assembly, which paid up to (but not beyond) its quorum of 6,000 citizens to attend" $(1995,156)$. He adds, "One other extremely important element in Athens' government was the jurycourt system" (156). The jurors were volunteers. They were selected and assigned to cases by lot. Verdicts were issued after only a single day's trial. "The litigants spoke for themselves; there were no professional prosecutors or defense lawyers" (156).

Plato's portrayal of the trial and death of Socrates is the most famous in the literary world. The four dialogues under study have been casually referred to as "dramatic" or "tragic" by many scholars. However, no attempt to my knowledge has been made to analyze them in this sense, or to show how they could be considered an integrated tragic tetralogy that has the basic elements of tragedy, showing Socrates as a victim rather than a culprit; as one who falls prey to Athenian democracy for political reasons rather than the much publicized religious accusation.

The term "tragedy" is defined by Plato's own notable scholar Aristotle in the principles he put forward in his Poetics as:

The imitation of a good action, which is complete and of a certain length, by means of language made pleasing for each part separately, it relies in its various elements not on narrative 


\section{Conflicting Versions of Tragic Socrates}

but on acting; through pity and fear it achieves the purgation (catharsis) of such emotions. (335 B.C., 49b emphasis mine)

This definition is further developed by Aristotle and each element shall be examined to see how far Plato's dialogues adhere to it and present a tragic Socrates.

First, concerning the term "imitation," Aristotle meant that the tragedian "deals with general truth" (51b), as opposed to the historian who is concerned with "specific events" (51b).

It could be well argued that Plato's Trial and Death of Socrates deals with the specific character of Socrates and with the specific events surrounding his trial and death. However, Plato masterfully rendered the tetralogy universal and allowed it to be highly philosophical through his dialectics which necessarily break away from the constraints of individual case to a wide array of philosophical thought that reflect on Socrates' multidimensional character. He covers such topics as religion, ethics, respect for the law and finally the immortality of the soul. Moreover, by being an "imitation" of the trial and death of Socrates, the dialogues adhere to Aristotle's elucidation, "tragedy is an imitation, not of men but of action and life, of happiness and misfortune" (335 B.C., 50a).

Second, regarding "acting," by requiring tragedy to rely on acting, not on narration, Aristotle draws the basic differences between drama and epic poetry to which he attributes the narrative form (49b). The Trial and Death of Socrates mainly depends on the dialogue as a form, with the exception of Apology which is a monologue spoken by Socrates, that makes use of rhetorical devices to devalue Meletus' accusation.

Plato's use of dialogue has been referred to by many researchers and scholars. Notable among them is Charles H. Kahn who attributes a literary dimension to Plato's dialogues, besides the philosophical one. He explicitly refers to Plato as "a great dramatist who belongs in the company of Shakespeare and the Attic tragedians" (1997, Preface, xiii). Plato's use of dialogue dramatizes Socrates' philosophical discussions, ascribing to them insightful and dynamic dimensions that suit well the argumentative 


\section{Heba H. El-ABBADI}

give and take and dialectic method so well known of Socrates. He thus intensifies the tragic outcome, for he skillfully brings the audience in touch with Socrates' philosophical wisdom and then allows it to experience the inconsistency in the development of the plot as the verdict is pronounced.

The form and style adopted by Plato is expected of one who, as I.F. Stone states, "originally wanted to be a playwright" $(1988,4)$ at a time when the theatre was esteemed as the primary literary genre. Martin Puchner expounds Plato's writing career by stating that Plato started as a "young playwright [who] submitted his tragedy to the annual competition at Athens" $(2010,3)$. However, when he saw a group of people listening to "the notorious public speaker Socrates" (3), he became infatuated with his "witty and ironic phrases [and] decided to become a student of this man" (3). Instantly deciding to change careers, "on the steps of the great Dionysius Theatre of Athens, he burned his play" (3). Puchner elucidates that Plato thereafter adopted a dramatic style and his subsequent writings "were richly conceived scenarios paying minute attention to setting, character and plot even as they deviated from all known forms of drama"(4).

The third term in Aristotle's definition, namely, "catharsis" is fully discussed when dealing with the resolution of the Dialogues. Attention has to be given to "plot" and "character" first.

In the Poetics, Aristotle stresses that "plot" is "the soul of tragedy" (335 B.C., 50b). He adds that the tragic plot should be "whole" (50b), meaning "having a beginning, middle, and an end" (50b). It should be initiated by a complication that unravels as the plot proceeds towards a turning point which is preceded by a "reversal," and followed by "recognition." Aristotle also refers to the unity of action whereby "the various incidents must be so constructed that, if any part is displaced or deleted, the whole plot is disturbed and dislocated" (51b). Second in importance to "plot" is the "character." The protagonist, as prescribed by Aristotle, is "a man who is neither outstanding in virtue and righteousness, 


\section{Conflicting Versions of Tragic Socrates}

nor is it through wickedness and vice that he falls into misfortune, but through some flaw. He should also be famous or prosperous" (53a).

In my opinion, Euthyphro, Apology, Crito and Phaedo constitute an integrated "whole" plot, forming a tetralogy. I, therefore, disagree with Kahn's reference to "the formal independence of the dialogues from one another" (1997, 37). He argues that "each dialogue presents itself as an autonomous unit, existing in its own literary space . . . In each case Socrates begins an entirely new conversation with new interlocutors" (37). He adds, "this formal autonomy makes it tempting, even desirable, to read each dialogue as if it were a complete literary unit and a thought - world of its own, like the individual plays of Shakespeare or Molière" (37).

It is my contention that the four dialogues in question work together beautifully as a whole to intensify the tragedy that befell Socrates. Each of the four dialogues constitutes incidents of a tightly constructed action that has "a beginning, middle and end" (Aristotle 335 B.C., 50b).

The first dialogue, Euthyphro, offers an exposition that introduces the initial conflict between the renowned philosopher and Athens which culminates in Socrates' trial and death, and provides insight into Socrates' character. Meletus has accused him of impiety and of corrupting the youth of Athens. Euthyphro points to Socrates' esteemed position when he envisions that by taking the case to court, Meletus "is simply aiming a blow at the state in a sacred place" (Plato 1992, 2). Once this notion of Socrates' fame is secured, Plato offers his readers one of the best examples of the Socratic Method in a dialogue that inquires into the meanings of piety versus impiety where Socrates leads Euthyphro out of his self confidence in being a master expert in religious issues and into a state of skepticism that leads him to end the conversation:

SOC: What is piety? . . . if any man knows, you are he; and therefore I shall detain you, like Proteus until you tell. For if you had not certainly known the nature of piety and impiety, I am confident that you would never, on behalf of a serf, have charged your aged father with murder. You would not have run such a risk 


\section{Heba H. El-ABBADI}

of doing wrong in the sight of the gods, and you would have had too much respect for the opinions of men. I am sure, therefore, that you know the nature of piety and impiety. Speak out then, my dear Euthyphro, and do not hide your knowledge.

EUTH: Another time, Socrates; for I am in a hurry, and must go now. (Plato 1992, 16-17)

We are then ushered into the Apology which, in my opinion, displays Aristotle's division of tragedy into rising action, reversal and climax of the tetralogy. It is worth mentioning that in the context of the Dialogues, the word "apology" does not mean a statement of regret. It rather means "a defense." The Apology starts with Socrates reporting Meletus' charges. Tension increases as the major conflict aggravates. We are led towards a rising action where the confrontation between Socrates and Meletus is made explicit, when the latter accuses Socrates that he is "an evil-doer, and a curious person, who searches into things under the earth and in heaven, and he makes the worse appear the better cause and he teaches the aforesaid doctrines to others" (Plato 1992, 21). In trying to reach the truth as dictated by the Oracle of Delphi, the tragic hero is involved in an inquest to gain knowledge, but at a very high stake. Indeed, he acknowledges that the search for "a man wiser than myself . . has led to my having many enemies of the worst and most dangerous kind, and has given occasion also to many calumnies" (23-24). Socrates' words reflect the traits of the Aristotelian tragic hero. Though wise, he is antagonized. Moreover, he is revealed as adamant, which in my opinion constitutes his "hamartia" or "error of judgment" or "mistaken assumption" as Marvin Carlson explains the term $(1993,19)$. Indeed, his adamancy in the pursuit of wisdom and probing questions that would embarrass his interlocutors alienates him from his society and causes him to underestimate the power that the society has in condemning him. The plot thus evolves towards a complication when the increasing number of enemies referred to, and the allusion to Aristophanes' Clouds function as obstacles that counteract 


\section{Conflicting Versions of Tragic Socrates}

Socrates' argument in the defense and cause further complication in the plot.

The reversal is then reached when Socrates is found guilty despite his apt defense, and the jury pronounces the "votes for condemnation" (Plato 1992, 36). This "change of the situation into its opposite" (Aristotle, 335 B.C., 52a), as Aristotle defines reversal, turns Socrates' fortune from happiness to misery, from "one who has name for wisdom," one who "is in some way superior to others" (Plato, 1992, 37) into a criminal whose accuser demands that he suffer the harshest of sentences. The reversal is followed by the "recognition" of the true feelings of Athenians towards him. Though he says that he "expected this" (36), the regretful tone is inescapable when he utters, "but now, had thirty votes gone over to the other side, I should have been acquitted" (36). Socrates also hints at the defective jury system within Athenian democracy when he explains that "without the assistance of Anytus and Lycon, [Meletus] would not have had a fifth part of the votes, as the law requires" (36), implying the weak points of the system that allows for demagogy, or appealing to the emotions of the public. Indeed, as Josiah Ober emphatically states, "Socrates is the protagonist of this story, but the antagonist is not just Meletus, but the polis of Athens: its citizens (qua judges), its established laws, and its democratic political culture" $(2011,138-178$, esp. 146). The trial is perceived as "a stark confrontation between the moral philosopher and the democratic city"(146).

The end of the Apology projects that Socrates' stance against the current democratic system is the real motive for his condemnation rather than the much promoted religious reasons. Mostafa El-Abbadi believes that 'the proof of Socrates' involvement in politics and of his relation with the secret movements involving aristocratic youth against democracy stands in the change of his tone and the acute way with which he speaks in the last part of the Apology after the court issues its final decree of death sentence" 


\section{Heba H. El-ABBADI}

(1993, 51-115, esp. 100-101) ${ }^{1}$. El-Abbadi adds that at that point, "instead of remaining calm and talking about gods and virtue, he suddenly resorts to threatening the court, foreshadowing what will happen to its members after his death" (101). Indeed, Socrates addresses them saying, "I prophesy to you who are my murderers, that immediately after my death punishment far heavier than you have inflicted on me will surely await you" (Plato 1992, 39). He adds:

Me you have killed because you wanted to escape the accuser, and not give an account of your lives. But that will not be as you suppose: far otherwise. For I say that here will be more accusers of you than there are now; accusers whom hitherto I have restrained: and as they are younger they will be more severe with you, and you will be more offended at them. For if you think that by killing men you can avoid the accuser censuring your lives, you are mistaken. (39)

El-Abbadi speculates that this threat proves Socrates' political ties:

It is very close to an admission on the part of Socrates that the accusation for which he was convicted and for which he was sentenced to death was, due to his constant antagonism towards democracy and also his intimate intellectual and academic relation with those who led the three minority revolts during the ten years preceding the trial. (1993, 51-115, esp. 100-101)

I.F. Stone also believes that "the case against Socrates was political and that the charge of corrupting the youth was based on a belief . . . that he was undermining their faith in Athenian democracy" (1979). He adds that the charge was brought against Socrates because the Athenians were afraid that history would repeat itself and antidemocrats would stage bloody revolutions and establish dictatorships. Stone elucidates that "even 50 years after the event, when there had been ample time for reflection and remorse the Athenians still regarded the trial as political, and the verdict as justified." His evidence lies in "a speech by the famous orator Aeschines

1 This quotation and others from Mostafa El-Abbadi's "Athenians' Democracy" is my translation from Arabic. The original Arabic text is in Note 5 at the end of this study. 


\section{Conflicting Versions of Tragic Socrates}

. . . in the year 345 B.C, just 54 years after the trial of Socrates," where he announces to the jury court, "you executed Socrates . . . because he was clearly responsible for the education of Critias, one of the thirty antidemocratic leaders" (Qtd in Stone 1979). Indeed, "Socrates' reputation still suffered from his association with Critias. The reference to Critias and Socrates proved effective demagogy. Aeschines won his case." (Stone 1979)

Gregory Vlastos supports the political nature of Socrates' trial. He mentions that "Socrates was a fomenter of oligarchic sentiment" and "perceived as a politically subversive teacher, and this perception of him would have certainly weighed strongly in the motives of the prosecution and in the minds of many of the jurors who had voted for his conviction" (1983, 495-516, esp. 497). He explains that the amnesty of 405 did not allow for the prosecution of Socrates for his political activities. Instead other charges were found:

And there is no evidence to the contrary. As has long been recognized, the fact that the imputation of subversion does not surface in the formal indictment does not constitute such evidence, for this fact is perfectly explicable by the amnesty to substantiate the imputation in court. Socrates' tutorial link to Critias or other leaders of the oligarchic coup would have had to be rehearsed, and this would have been a violation of the amnesty. Thus Socrates could only have been formally indicted on charges which either were not political at all—not believing in the gods of the state and introducing new divinities-or only indirectly political: corrupting the youth. (497)

The climax of the tetralogy is reached when the jury refuses Socrates' suggestion of paying a fine of thirty minae, and condemns him to death. With a dignity that befits a tragic hero, Socrates accepts his fate and starts seeing the positive aspects of death when he declares:

Let us reflect in another way, and we shall see that there is great reason to hope that death is a good, for one of two things: either death is a state of nothingness and utter unconsciousness, 


\section{Heba H. El-ABBADI}

or, as men say, there is a change and migration of the soul from this world to another. (Plato 1992, 40)

The final resolution is unfolded in Crito and Phaedo where Socrates embraces death and philosophizes about the immortality of the soul.

When Crito opens, Socrates is seen to have been in prison for a month. His friend Crito urges him to escape only to find an adamant and unyielding Socrates who bravely declares that he wants "to abide by the sentence of the state" (Plato 1992, 50). Till the end of the Crito, Socrates stands by his values and urges his friend to let him "follow the intimations of the will of God" (54). The ethical dimension of his wish as well as his display of a sense of peaceful submission rather than a tragic reaction to his fate, have tempted scholars to disregard the tragic aspect of the Trial and Death of Socrates. Hyland, for example, believes that "Socrates does not respond to his tragic realization in the manner of the usual tragic hero, with the well-known tragic lament. He responds instead with an essentially comic reaction: a smile, happiness" (1968, 38-50, esp. 49). Hyland adds that "Socratic happiness offers us a characterization of the highest form of comedy: comedy is purchased at the price of the tragic realization, but transcends the tragic lament" (49). Gill Gordon also "sets the dialogues apart from Attic tragedy" $(1999,82)$ which as he argues "is tragic for the very reason that it depicts the fall of good men" (82). He says the last three dialogues "reverse [Socrates'] fate of death as the worst misfortune to befall man" (82). First, I deny the dialogues any comic aspect and do not see Socrates as a "comic fool-hero" (48), to use Hyland's words. Second, Socrates' misfortune is neither "seeming," nor is his "impending death reversed" according to Gordon (82).

He is a tragic hero par excellence, who displays tragic aspects that cannot be denied. He is adamant in pursuing his mission despite threats and dire accusations till he is condemned by a democratic society that has the power to execute a man in Socrates' stature. When at the end he does not exhibit any pitiful reactions and is comfortable with the idea of dying due to his belief in the immortality of the soul, Socrates acquires an extra 


\section{Conflicting Versions of Tragic Socrates}

dimension. He gains grandeur and transcends his plight by a seeming submission and hence challenges the condemnation, and conquers his opponents.

The Phaedo ends the tetralogy with a discussion on the Theory of Forms, as well as several arguments dealing with the immortality of the soul and favouring philosophical life. It is also significant as an account of Socrates' final hours. Phaedo relates Socrates' state and his own emotions during these hours:

... his mien and his language were so noble and fearless in the hour of death that to me he appeared blessed. I thought that in going to the other world he could not be without a divine call, and that he would be happy, if any man ever was, when he arrived there; and therefore I did not pity him as might seem natural at such a time. But neither could I feel the pleasure which I usually felt in philosophical discourse ... I was pleased and I was also pained, because I knew that he was soon to die, and this strange mixture of feeling was shared by us all; we were laughing and weeping by turns ...

(Plato 1992, 56 emphasis mine)

This mixture of emotions is significant. Socrates' disciples are pained due to the tragic dimension of the end of one who was far ahead of his times, yet they seem pleased and fail to pity him as a result of his own attitude, an attitude that negates fear of death. Socrates is apt in explaining his own state of mind when he attributes pleasure to pain and vice versa because he will be physically tortured in order to rise in stature:

How singular is the thing called pleasure, and how curiously related to pain, which might be thought to be the opposite of it, for they never come to a man together, and yet he who pursues either of them is generally compelled to take the other. They are two, and yet they grow together out of one head or stem ... and this is the reason when one comes the other follows, as I find in my own case pleasure comes following after the pain in my leg which was caused by the chain. (Plato 1992, 58) 


\section{Heba H. El-ABBADI}

Despite the disciples' earlier account of pleasure and lack of pity, the account of attending the final moments before Socrates' death leaves no doubt that they are perturbed and disturbed to the extreme:

Then holding the cup to his lips, quite readily and cheerfully he drank off the poison. And hitherto most of us had been able to control our sorrow; but now when we saw him drinking, and saw too that he had finished the draught, we could no longer forebear, and in spite of myself my own tears were flowing fast; so that I covered my face and wept over myself, for certainly I was not weeping over him, but at the thought of my own calamity in having lost such a companion. Nor was I the first, for Crito, when he found himself unable to restrain his tears, had got up and moved away, and I followed; and at that moment, Apollodorus, who had been weeping all the time, broke out into a loud cry which made cowards of us all.

(Plato 1992, 115 emphasis mine)

The weeping of the disciples contrasts sharply with Socrates' attitude, for he has retained his dignity and assumed his tragic responsibility. He rebukes his disciples with, "What is this strange outcry? . . . I sent away the women mainly in order that they might not offend in this way, for I have heard that a man should die in peace. Be quiet then, and have patience." (115). Shortly after, according to Phaedo:

He was beginning to grow cold about the groin . . . and said (they were his last words) - he said: Crito, I owe a cock to Asclepius; will you remember to pay the debt? The debt shall be paid, said Crito; is there anything else? There was no answer to this question; but in a minute or two a movement was heard, and the attendants uncovered him; his eyes were set, and Crito closed his eyes and mouth. (Plato 1992, 115)

Socrates' death thus brings about a seeming resolution: In the eyes of the state, order is established, and yet Socrates gains in heroic dimensions.

The past speeches lead to the last element in Aristotle's definition of tragedy to be examined, namely, catharsis. The term "catharsis" is quite problematic for scholars. Marvin Carlson traces the different possible 


\section{Conflicting Versions of Tragic Socrates}

meanings of the term. He refers to the most popular interpretation as signifying "purification" (1993, 18). Indeed, Harold Skulsky ascertains that by "catharsis" Aristotle "refers to a special kind of pleasure or purification of perception, one which proceeds from dispositions similar to pity and fear (1958, 147-160, esp. 150).

Carlson also refers to Leon Golden's theory "that what takes place in the spectators of tragedy is a sort of intellectual enlightenment, whereby they see how disturbing emotions fit into a unified, harmonious world" (1993, 18). Indeed, Golden understands catharsis as "clarification' in the intellectual sense of the word" (1962, 51-60, esp. 58), and proposes that the final clause in the definition of tragedy in Chapter 6 of the Poetics be translated thus, ". . . achieving, through the representation of pitiful and fearful situations, the clarification of such incidents (59).

If we revert back to Plato's tetralogy, the most pressing question would be: how does it affect its audience? How does it emerge out of the whole experience surrounding the trial and death of Socrates? On the one hand, if the events are taken at face value, then the simple terms of "pity" and "fear" definitely apply. We wonder how such a philosopher who was much esteemed in Athenian society is easily condemned and put to death. Fear is also a strong resulting emotion for, as human beings, we fear equally for ourselves that we would face a similar fate. Moreover, on a deeper level, the Trial and Death of Socrates audience emerges more "enlightened." Plato's work carries deep meanings that any intellectual is bound to delve into where his inquisitive mind would start to search for truths only to arise more illuminated.

On the two stated levels, the issue of democracy is significant because on the one hand, we pity Socrates for being the victim of democracy and at the same time we fear being harmed by it. On the other hand, our minds are stimulated to question the real reasons behind his being found guilty. We then become informed by Socrates' own teachings and thus start our own dialectical process in order to reach the ultimate truth. 


\section{Heba H. El-ABBADI}

The discussion of democracy and its role in condemning Socrates ushers us into Clifford Bax's version of the events surrounding his trial and death. Bax is a prolific British writer who has written many plays ranging from fantasies to histories to adaptations such as Socrates. However, to my knowledge, there is no critical material available in books, periodicals or online that assesses his work, except for Allardyce Nicoll's brief mention in World Drama from Aeschylus to Anouilh. Nicoll states that in writing Socrates, Bax is "less interested in action than in words. It is on his dialogue he concentrates, and few writers ... have a finer sense of the jeweled phrase than he" (1950, 864).

Bax's ambition in writing Socrates extends beyond his fascination with the philosopher or admiration with his dialectics. He introduces innovations by bringing to life many of the events that Plato denied his audience in the tetralogy to suit his purposes. Scene i, for example, shows the fascination of Socrates' pupils and various samples of the interaction between the philosopher and his disciples. Bax also attempts to shed light on Athenian democracy and its role in Socrates' condemnation. He then skillfully uses Socrates' ideals and political stance in order to project them to contemporary early twentieth-century social and political issues in Britain. These projections allow him to delve deep into his own culture, criticize certain ideologies, in addition to subtly suggest alternatives.

A philosophical discussion on democracy figures prominently in the play, including the implications of the term, promoting such notions as respect, equality and justice:

Lycon: Democracy is the government of men by their own consent. It is based upon universal respect for man.

Anytus: If every man is required to fight for his country, every man should have an equal voice in making his country worth fighting for.

Meletus: Democracy means the end of privilege and oppression. (1930, 515)

After establishing these positive notions, Bax shocks his audience with Socrates' opinion which is pronounced with an explicit denunciation, “. . . 


\section{Conflicting Versions of Tragic Socrates}

if an army without a supreme head becomes a rabble . . . I cannot understand how an entire State can best be governed by the whole populace" $(1930,518)$. Bax, then hints at the indictment formulated against Socrates, as well as at the corruption within the judicial system. Indeed, Crito admits, "My boy, it won't be a fair fight. That's the trouble. His enemies have poisoned the minds of a great many citizens. At least half the judges are convinced that Socrates aims at nothing but the destruction of the present social order" (530). Socrates' stance against the extant political system is thus established, expressing Bax's rejection of the religious accusation that condemns Socrates and not only affirming the political allegation, but also supporting the demagogical aspect attached to Athenian democracy.

By introducing this issue, I believe that Bax is not only shedding light on Socrates' tragedy, but is also articulating his own antagonistic attitude towards events closely associated with democracy in early twentieth-century Europe.

First, the most important social and political event in early twentieth-century England is the passing of The Franchise Act of 1928 which granted women full equality with men to vote in elections and they "became the majority of the electorate" ("Equal Franchise Act"). Many women, and particularly men, at the time had their reasons to stand against women's suffrage. They argued that "on the one hand, women were considered too precious and innocent to become embroiled in public life, on the other they were thought too irrational and emotional to make an intelligent contribution. Whatever their abilities, their place was thought to be in the home" (Van Helmond 1992, 72). The parallels between the anti women's suffrage arguments and Socrates' discourse are obvious. Antisuffragists could not perceive how women could be equal to men and would be adequately able to vote and stir the political life of England. Similarly, Socrates, as Paul Cartledge states, "argued that the majority of the people, because they were by and large ignorant and unskilled, would always get it wrong" (2011). Indeed, in such an intellectual's view, 


\section{Heba H. El-ABBADI}

"government was an art, craft or skill, and should be entrusted only to the skilled and intelligent, who were by definition a minority" (Cartledge 2011). The implied attitude against women voters and the way Socrates perceives the populace is identical:

[He] denied specifically that the sort of knowledge available to and used by ordinary people, popular knowledge if you like, was really knowledge at all. At best it was mere opinion, and almost always ill-informed and wrong opinion. (Cartledge 2011)

Second, the major political event that resulted in explicit disappointment in democracy is World War I. Many became disenchanted with democracy as a political system. As Roland N. Stromberg points out, "the effect of the war and the peace settlement of 1919 was a profound disenchantment among the victorious peoples almost as much as among the defeated" (1996, 86 emphasis mine). He adds prominent intellectuals' points of view that were skeptical towards the War as well as towards democracy. D.H. Lawrence for example is quoted as declaring "No man who has lived through this [War] can believe again absolutely in democracy" (86). Indeed, the European intelligentsia, with the British figuring prominently amongst them, explicitly spelled out "democratic inefficiency" (86) and yearned for an alternate regime. Many of them favoured the trend adopted by certain countries in Europe which turned to dictatorships. They thus "hailed Mussolini as well as Lenin ... [and] in the 1920s they were implicated in fascism" (91).

Third, the major economic event during the late nineteen twenties was the Great Depression of 1929. As Ernest Barker points out, "Democracy in its nature has always carried economic implications" (1958, 100). With the overexpansion of businesses and industry in the United States, "prices fell, and industries had to cut down production and fire workers" (Okun and Bronz 1973, 632). This process caused the Depression whereby:

. . . stock prices unexpectedly went down in October 1929.

[Thus,] thousands expected stock prices to keep falling, and so 


\section{Conflicting Versions of Tragic Socrates}

sold their shares for what they could get. The stock market was flooded with shares of stocks, and so prices fell even more. For a few days a group of bankers and investors tried to keep prices from falling. But on October 24-"Black Thursday" - the market collapsed. (632)

The effects of the crisis on Wall Street were soon to affect British economy in the nineteen thirties. Bax could only foresee such a disaster. His criticism of democracy in Socrates is thus also seen as a warning against the economic implications associated with it.

The scenes in Bax's intertext are to a great extent similar to Plato's own account. The information and the choice of words in Socrates' defence in Scene v are, for example, identical to those in Plato's Apology. However, the trial in Bax's play has a different impact than Plato's. The audience here does not feel the tragic intensity produced by Plato since they are removed from the ancient Greek world which is rich in mythology and the supernatural element. George Steiner explains this phenomenon in The Death of Tragedy. He states in reference to classical drama that "the tragic personage is broken by forces which can neither be fully understood nor overcome by rational prudence" $(1961,8)$. He elaborates that there is a hidden force outside or within man that destroys him, or punishes him excessively. "There is no use asking for rational explanation or mercy. Things are as they are, unrelenting and absurd" (9). However, this powerless and broken tragic hero "assumes a new grandeur" (10). Indeed, "in Greek tragedy as in Shakespeare, mortal actions are encompassed by forces which transcend man" (193), but as Steiner believes, in modern times, "the tragic voice in drama is blurred or still" (10). His theory assumes that this kind of tragic drama is not possible within the modern scientific and technological progresses; for they offer no logical explanation to the hidden powers that have the ability to transform man from bliss to misery while allowing him to emerge with tragic stature. Larry Brown explains that "the triumph of rationalism and a secular world view has removed the metaphysical grounds for tragedy in the modern 


\section{Heba H. El-ABBADI}

world" (2010). He adds, "Modern man will have no such overlords, and with his sciences and skeptical reason he has conquered his superstitious belief in the unseen realm."

Nevertheless, Bax's play is pessimistic. It ends with Socrates' death in scene vi after refusing to escape as Crito suggests. The scene is equivalent to Plato's Phaedo, which gives a second-hand account of Socrates' final hours through Phaedo. However, though Bax's account is first-hand, it fails to achieve the same effect as Plato's. In Phaedo, the force of the tragedy is deeply felt due to the way Phaedo expresses his and his friends' feelings. These sentiments are not conveyed in the last scene of Socrates. Instead, Bax focuses till the end of the play on Socrates' mastery in arguing and counter-arguing through dialectics till "he is gone-like a ship to the sea" (578) with music playing in the background. The ending is thus reached without the intense emotions stirred by classic tragedies. In my opinion, there are two reasons for such a closure and drawing away from the tragic besides Steiner's own speculation. First, to a modern audience, Socrates is not really dead. In scene vi, the character of Socrates says, "If [Plato] remembers me in his writings, the men of the future may also remember me" (553). Indeed, Socrates' legacy is alive well into the twenty-first century through Plato's Socratic Dialogues. Second, the dire effects of World War I were tragic in the true sense of the word and playwrights like Bax could not envision any tragedy compared to the tragic outcome that inflicted Europe. In Europe, millions lost their lives and in England the seeds of the decline of the British Empire were apparent after the War due to the rise of nationalist awareness in colonized countries and the call for independence. Moreover, one of the tragic effects of the War on England was its dept to the United States after being exhausted due to war costs, and thus the shift of the world's financial center from London to New York. Indeed, "the first World War and the 1920s had seen the inexorable rise to global power of the American economy and the dollar" (Smith 1998, 21). As Vladimir Lenin (1870-1924) aptly puts it, the term democracy was perceived as a deceptive catchword used by the capitalists 


\section{Conflicting Versions of Tragic Socrates}

and their press $(1939,10)$. Lenin draws a link between Capitalism and democracy and proposes that these systems oppress the people of the world for their financial gain. In a satiric tone, he says "this 'booty' is shared between two or three powerful world marauders armed to the teeth (America, Great Britain, Japan), who involve the whole world in their war over the sharing of their booty" (10).

The issue of democracy is picked up again in Maxwell Anderson's Barefoot in Athens. It is worth mentioning that it did not have any favourable theatrical reviews, and literary critics had many reservations concerning it. They criticized its lack of vitality and emphasized its weaknesses. John Brown, for example, condemns it as "a curiously drab and disappointing work. It is slow in getting started and awkward in some of its means" $(1952,203)$. George Nathan too criticizes it as "a serio-comic crayon portrait of a gray-bearded and somnambulistic fifth century Monly Wooley clad in an amplitudinous peignoir and mouthing benign sentiments on the right of man to express himself in a democratic society" $(1953,41)$. He adds, "it is and has been Mr. Anderson's misfortune to challenge us to expect too much of him" (41).

Nevertheless, I believe that Barefoot in Athens is a fine play, particularly with reference to Anderson's views stated in his letters and critical articles, namely, "Poetry in the Theatre" and "The Essence of Tragedy." In a letter dated September 5, 1950, Anderson writes, "the play was not aimed at New York" $(1977,245)$. It is "a play about Athens, for the Athenians ... . not at all sure it will be found suitable for local presentation" (246). In other words, Anderson foresaw the New York failure and expected that the dramatization of Socrates' firm hold of the values of democracy in the face of Spartan dictatorship to be appreciated by a Greek audience. The play explicitly draws similarities between the political system of ancient Sparta and Communism: "A small group of men take the whole burden of the government on themselves, so that the average citizen never has to worry about it at all" (Anderson 1939, I.3.47). By inquiring more into this system, Socrates concludes that it is "a governing 


\section{Heba H. El-ABBADI}

class of freebooters and murderers, holding the population down by terror and strict controls" (47). Only a Greek audience, rather than an American, would identify with these statements.

Significantly, three years prior to writing Barefoot in Athens, Anderson visited Greece. While there, he sent to the New York Herald Tribune reports "on the conflict between the Communist-led guerrillas in the north and the elected government in Athens ... he believed that it was more legitimate and offered more freedom to its citizens than would any regime backed by the Communists" (Tees 1980, 5-11, esp. 9).

However, the tackling of Communism has another function. Socrates' obvious condemnation of Communism and his nostalgia towards the former free democratic system by which Athens was ruled is also used as a warning to a Communist threat back home. In "Poetry in the Theatre," Anderson refers to the stage as "a cathedral, but just now a journalistic one, dominated by those who wish to offer something immediate about our political, social or economic life" (1939, 16-21, esp. 19). Thus, the contemporary American political arena is reflected in the play, especially that it was written when "many people worried that Communists were gaining a dangerous amount of American support and power" (Okun and Bronz, 1973, 745). Indeed, "in September 1950 Congress passed the McCarran Act to limit communist activities in the United States and prevent immigrants who had belonged to Communist organizations in Europe from entering the country" (745).

Maxwell Anderson was "a passionate believer in democracy" (Brown 1952, 199) and regarded members of the Communist party as traitors. He viewed their activities not as political, "but criminal" (Anderson 1977, 255). In answering an accusation that he was "inconsistent in supporting freedom of speech in the play and opposing it in the current situation" (Avery 1977, 257), Anderson defended himself by saying, "Socrates maintained the right of anybody to speculate and converse on any subject. He did not defend those who betrayed their country" (255-6). Indeed, during the trial scene, there are references to his 


\section{Conflicting Versions of Tragic Socrates}

disciples Alcibiades, Charmides and Critias who sold out their city in favour of its enemies, and Socrates is apt at denouncing them:

When a man is free he is free to choose wrong or right. In a free city no man chooses for another. I did not choose for Alcibiades or Charmides or Critias. I have chosen only for myself. For myself I chose to fight for Athens. (Anderson 1951, II.ii.84)

Thus, as Joshep T. Shipley states:

We watch Socrates in Athens of the fifth century B.C, but we think also of the twentieth century, now. And we recognize that democracy has deeper roots in the world today, since it no longer rests on a majority enslaved; but it faces the same great problems welling out of the nature of man: indifference and corruption within, jealousy and tyranny abroad. Such a choice as Socrates' keeps the ideal alive. Such a play as Anderson's keeps the theatre worthwhile. $(1956,36)$

"The Essence of Tragedy" in which Anderson expounds his unique vision of the tragic hero is of paramount importance to examining Barefoot in Athens. His formula is "a modern version of Aristotle" (1939, 43-51, esp. 47) and he follows much of the dictates of the ancient Greek critic. However, he emphasizes certain aspects that he later applies to his Socrates:

In the majority of ancient and modern plays it seems to me that what the audience wants to believe is that men have a desire to break the molds of earth which encase them and claim a kinship with a higher morality than that which hems them in. (50)

Anderson stresses hope and optimism in the face of oppression. As Halline elucidates, "the good impulses within the protagonist must be dominant, thus rendering him a good person, and ... he must emerge at the end of the play with some type of supremacy over those impulses representing evil" (1944, 63-81, esp. 64-5). I believe that Anderson's depiction of Socrates represents the type of tragic hero who "transcend[s] ennoblement in the face of disaster" (65) to use Anderson's tenets. He does not allow any power to curb him from following his conviction till the end. 


\section{Heba H. El-ABBADI}

The central crisis of the play is dramatized when the indictment against Socrates is announced. Identical to Plato's charges, Socrates is to be tried because "he is guilty of crime, first because he does not worship the gods of our city, but introduces new divinities of his own; second because he corrupts the thinking of our young men" (Anderson 1951, 1.i.13). Instead of proceeding directly to the trial, however, Anderson makes an addition that breaks away from his predecessor. He gives his audience insight into the historical events surrounding Socrates and gives a detailed dramatization of Spartan rule in Athens. As the action proceeds, Anderson provides several examples of Socrates' dialectics and establishes him as a fervent supporter of democracy, denouncing any other system that strips a person of his freedom. He cannot miss a chance to assert that "the most valuable thing a man or a state could have was freedom" (Anderson 1951, I.ii.29). As Anderson pictures him, Socrates favours the democratic system that rules through "the citizens - the voters" because "Nobody can be trusted with power" (Anderson 1951, I.iii.46). He thus urges Pausanias, "Give us back our democracy!" (48). Significantly, Pausanias reminds Socrates that he stands the threat of being tried if the democratic system is re-established, "If Athens goes back to being a democracy you won't be safe here. You'll be tried on that same old charge they nailed up against you once" (I.iii.49). But Socrates prefers democracy over oligarchy and announces, "the courts are my protection" (49).

In keeping with Anderson's concept of the tragic hero, Socrates welcomes the trial when democracy is restored. He refuses Phaedo's and Crito's suggestions of doing things that would allow the jurors to sympathize with him. Thus, he "look[s] forward to this trial as an athlete [who] looks forward to the race he has longed for" (Anderson 1951, II.i.66). He significantly declares, "Day after tomorrow is my day!" (II.i.66). Socrates is tried and the jurors vote for the death sentence, to which he reacts by announcing "a martyr's death sends a man off in a blaze of excitement and a blare of argument!" (II.ii.87). This statement allows the 


\section{Conflicting Versions of Tragic Socrates}

audience an insightful example of nationalism and dedication to one's cause to the extent of willingly dying for its pursuit.

Act 2, scene iii of Anderson's intertext echoes Plato's Crito and Phaedo in the tetralogy. Socrates is in prison awaiting his death, a death he willingly accepts rather than betraying his ethics, for "all his life [he's] been saying it is better for a man to die than to do what his soul believes to be wrong" (Anderson 1951, I.ii.34). However, by the end of the scene, there is a major shift from Plato to accentuate Socrates' character as a bearer of high morality. King Pausanias offers to buy his escape and offers him freedom in Sparta, ironically, on condition that he does not wander about the streets. Socrates concludes a lengthy argument with the Spartan king with the firm statement, "it's better to die than to live not free" (Anderson 1951, II.iii.99).

The audience might wonder at the trial and death sentence of Socrates by a playwright who was an ardent believer of democracy and a fervent critic of Communism. Why would he dedicate a large part of the play to what Arthur Tees calls "the darker side of Athenian democracy?" $(1980,6)$. Anderson himself announces in the Preface to the play that the trial had been an "outstanding miscarriage of justice" (1951, xv) and that "the indictment was based on a complete misunderstanding of Socrates' motives" (xiv). However, in allowing the execution of his hero, Anderson believed that he was eternalizing Socrates' name and his dedication to his cause. Anderson emphasizes that in facing the death sentence and in refusing the possibility of escape, Socrates' loyalty to Athens is stressed. He explains that "he had fought against the verdict but once it became a fact he accepted it and would not revolt against it by running away (xiv). By picturing such a faithful Socrates, Anderson is actually endorsing his position as an advocate of democracy and shows his respect for the law. In fact, as Edward Forster emphasizes, with reference to Anderson's message in Key Largo (1939-40), "No man of sense dies of glory, yet a man will die for that which he deeply believes - for the essential values of Western Civilization, for personal freedom and integrity" (1942, 87-8). 


\section{Heba H. El-ABBADI}

Thus, Socrates drinks the hemlock, but unlike Plato's or Bax's protagonists, he dies reciting a prayer:

Beloved Pan, and all you other

Gods who haunt this city ...

Give me beauty in the inward soul

For outward beauty

I'm not likely to have...

May I reckon the wise to be wealthy ...

And those who need least to be most like the gods.

(Anderson 1951, II.3.101)

John Brown points out the weakness of this ending as opposed to Plato's. He says, "The heart-tearing serenity and the glory of the old man's dying disappear" $(1952,204)$. However, I believe that the ending is suitable, for it shows his feeling of contentment for being true to his beliefs till the last moment.

Finally, the Trial and Death of Socrates recounts the tragedy, not only of Socrates, but also of the concept of direct democracy in Classical Athens which depended on the citizens to stir the wheel of government. Though seeming fair because it empowers the people to make their own decisions, Socrates' tragedy accentuates its disadvantages. In all three works under study Socrates has been portrayed as a victim of such a regime. The trial does not show any logical development from the moment he is summoned to his execution. The audience is left to wonder why would such an esteemed man who dedicated his time to teaching his pupils how to argue and reach ultimate truth be put to death. There are of course the political reasons, but Socrates was not an oligarch, neither was he an antidemocrat in the sense of rejecting equality, justice and respect for the law. Instead, he regarded these notions highly, especially since he immediately answered the call to trial, trusted the judgment of the jurors and accepted the final verdict without any kind of disdain. As a matter of fact, he embraced it and respected it to the point of refusing banishment or escape, and instead he patiently obeyed the law awaiting his death sentence by looking forward to the positive outcome of moving to the other world. 


\section{Conflicting Versions of Tragic Socrates}

What Socrates criticized was the negative effects of direct democracy to which he himself fell victim. Direct democracy opens the door for demagogy. Indeed, as Giovanni Sartori states, "democracies are exposed to, and suffer from, demagogic escalations far more than anything else" (1987, 121). It "only shifts popular sovereignty from the locuses where it maintains a capacity for judgment and reasonableness to settings where it loses it" (121). Thus, in Socrates' case, besides his association with Critias, Aristophanes' Clouds has inevitably played that role. Jurors were familiar with the comedy and their minds were easily swayed by the caricatured portrayal rather than the evidence against him. As Thomas Brickhouse states, "One of the slanders . . f for which Aristophanes bears at least some of the responsibility, is that Socrates is an Atheist" $(2004,87)$. The type of government Socrates called for involved experienced, specialized and skilful politicians, who would run a government that promoted justice and equality. Indeed, Socrates' memorable words attacking Athenian Assembly in Phaedrus sum it all:

SOCRATES: Then when the orator who does not know what good and evil are, undertakes to persuade a state which is equally ignorant, not by praising "the shadow of an ass" under the name of a horse, but by praising evil under the name of good, and having studied the opinions of the multitude persuading them to do evil instead of good, what harvest do you suppose his oratory will reap thereafter from the seed he has sown?

PHAEDRUS: No very good harvest.

(Plato 1925, 260)

In conclusion, this paper has attempted an analysis of three presentations of the character of Socrates. Plato portrays him as a purely Aristotelian tragic hero in a tetralogy that traces his career from the esteemed philosopher to one who faces a tragic end and is executed. Modern playwrights have found in Plato's account of the death and trial of Socrates fertile grounds to express their own concerns for their contemporary societies. Thus, their audiences perceive the same events differently. On the one hand, Bax's intertext uses Socrates' stance against 


\section{Heba H. El-ABBADI}

Greek democracy to condemn what he saw as negative effects of modern democracy on the social, political and economic levels. His Socrates is an adaptation that lacks the tragic intensity portrayed by Plato, not only because it is a modern play written and produced in a scientific age far removed from the mythological world of ancient Greece, but also because of the tragic trauma the modern world has experienced during World War I. On the other hand, Anderson's treatment of his protagonist is a variation of Aristotle's concept of the tragic hero. His Socrates devotes himself completely to his principles, and Anderson uses him to condemn Communism, which he saw as a threat to established democracy. Anderson's variation of Socrates is thus an advocate of democracy who faces death due to his belief in freedom and his conviction that a person should never sacrifice his ideology. Instead, he has to defend it and preferably die a martyr for a cause rather than give in to oppression.

\section{Notes}

${ }^{1}$ It is worth mentioning that Egyptian intellectuals have been affected by Socrates' tragedy. First, esteemed Professor Etman produced A Belle in the Prison of Socrates which traces Socrates' trial, imprisonment and execution under the mandates of restored Athenian democracy. In the play, "noteworthy variations on the central theme play with temporalities to introduce Plato's journey to Egypt as a cultural encounter between Greek philosophy and Egyptian wisdom while Socrates is enabled to probe the relationship between law and popular demonstrations in the operations of Democratia" (Hardwick 2008, Preface). Most importantly, Etman's play touches upon the causes of Socrates' tragedy for he offers a "bold criticism of politics and politicians in Athens, which raises the slogan of democracy but in fact takes demagogy as its path" (Obeid" 2004, 7). Second, distinguished historian Abdel Hamid El-Abbadi ${ }^{4}$ has written a poem entitled "Socrates' Tragedy" in which he explicitly shows the high value of the philosopher who faces death due to the ignorance and ingratitude of his people. He also touches upon Socrates' ethics and respect for the law in the following excerpt:

$$
\begin{aligned}
& \text { ما كنت إلا رَوضةً فتانةً ...... و بَنو أبيك متاهةً جدباءَ }
\end{aligned}
$$

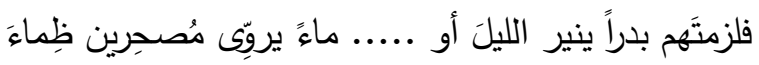

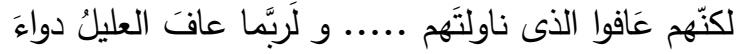




\section{Conflicting Versions of Tragic Socrates}

$$
\begin{aligned}
& \text { كتبوا عليكَّ الموتَ تشربُ كأسَها ..... فرضيتَ لا جَزِعاً ولا بكاءَ } \\
& \text { (00-0 1907) }
\end{aligned}
$$

${ }^{2}$ Lorna Hardwick's quotation is from Preface to A Belle in the Prison of Socrates (2008) by A. Etman. Newcastle: Cambridge Scholars Pub.

${ }^{3}$ Issac Obeid's quotation in note 1 is my own translation from the following Arabic:

"...مع تعريج نقدى جريء للسياسة و الساسة فى آَثينا التى ترفع شعار الديمقراطية لكنها تسلك

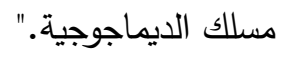

المصدر: مقدمة لمسرحية أحمد عتمان, حسناء فى سجن سقراط (ع ... (ألقاهرة: دار الثقافة

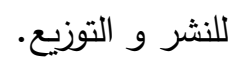

${ }^{4}$ The excerpt of verses from Abdel Hamid El-Abbadi's poem was originally published by Dar El Helal in November 1956.

The translation of the excerpt of verses into English is my own:

You were like a beautiful fertile garden and your contemporaries were like a barren desert. / Your company was as enlightening as a full moon that lights the night or like water that quenches the thirst in the desert./But they rejected with disdain what you offered them like a sick man who rejects healing medicine./They voted for your death by hemlock and you accepted without fear or tears.

${ }^{5}$ Arabic original of Mostafa El-Abbadi's quotations on pages 7-8 of this study.

ولعل اكبر دليل على تورط سقراط السياسى و علاقته بحركات الثباب الأرستقراطى السرية ضد

الايمقراطية, هو تغير لهجته و حدته التى غلبت على القسم الأخير من "الدفاع" بعد أن أصدرت

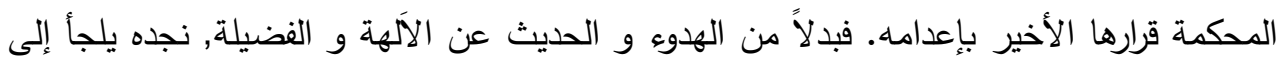

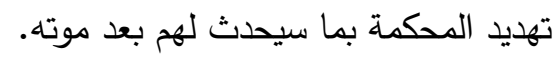

هذا يقترب من أن يكون اعترافاً من سقراط بأن الاتهام الذى حوكم و أعدم بسببه كان سياسياً

وذلك بسبب عدائه المستمر ضد الديمقراطية و علاقته الوثيقة فكرياً و تعليمياً على الأقل بالرجال

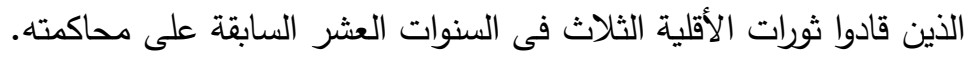

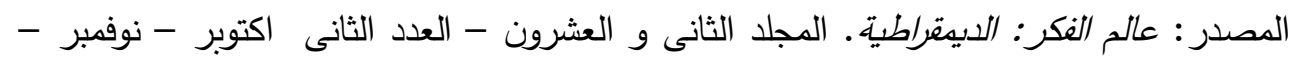

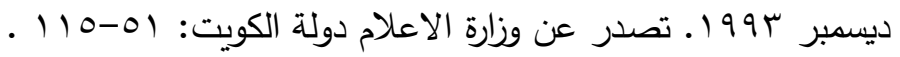




\section{Heba H. El-ABBADI}

\section{Works Cited}

Anderson, M. 1939. "Poetry in the Theatre." In: H. Frenz (ed.), American Playwrights on Drama. New York: Hill and Wang: 16-21

--- 1939. “The Essence of Tragedy." In: H. Frenz (ed.), American Playwrights on Drama. New York: Hill and Wang: 43-51

--- 1951. Barefoot in Athens. York: The Maple Press.

--- 1977. "Letters." In L. Avery (ed.) Dramatists in America: Letters of Maxwell Anderson, 1912-1958. Chapel Hill: University of North Carolina Press.

Aristotle 335 B.C. The Poetics. Trans. G. Grube. Indianapolis: Hackett Publishing, 1958.

Barker, E. 1952. Reflections on Government. Oxford: OUP.

Bax, C. 1930. Socrates. London: Victor Gollancz.

Brickhouse, T.C. and N.D. Smith. Routledge Philosophy Guidebook to Plato and the Trial of Socrates. NY: Routledge.

Brickhouse, T.C. and N.D. Smith 1995. Plato's Socrates. NY: OUP.

Brown, J. 1952. As They Appear. New York: McGraw Hill.

Brown, L. 2010. “Tragedy after Aristotle.” Retrieved on 10 Dec. 2012 from http://larryavishbrown.homestead.com/ Tragedy_after_Aristotle.html.

Carlson, M. 1993. Theories of the Theatre: A Historical and Critical Survey from the Greeks to the Present. Cornell: Cornell U P.

Cartledge, P. "Critics and Critiques of Athenian Democracy." Retrieved on 25 Feb. 2012 from http://www.bbc.uk/ history/ancient/greeks/greekcritics.

Dollimore, J. and A. Sinfield. Political Shakespeare: Essays in Cultural Materialism. Manchester. Manchester UP, 2003.

El-Abbadi, M. 1993. "Athenians' Democracy." The World of Thought 22(2): 51-115. [In Arabic]. 


\section{Conflicting Versions of Tragic Socrates}

"Equal Franchise Act." Retrieved on 2 January 20012 from http://www. parliament.uk /about/livingheritage/transformingsociety/ womenvote/parliamentarycollections/equal-franchise-act-1928/

Fischlin, D and M. Fortier (eds) 2000. Adaptations of Shakespeare: A critical anthology of plays from the seventeenth century to the present. NY: Routledge.

Golden, L. 1962. "Catharsis." Transactions and Proceedings of the American Philological Association 93: 51-60.

Gordon, G. 1999. Turning Towards Philosophy: Literary Devices and Dramatic Structure in Plato's Dialogues. Pennsylvania State University Press.

Halline, A. 1944. "Maxwell Anderson's Dramatic Theory." American Literature 16 (2): 63-81.

Hayland, D. 1968. "Why Plato Wrote Dialogues." Philosophy \& Rhetoric 1 (1): 38-50.

Helmond M. V. 1992. Votes for Women: the events on Merseyside. Liverpool: National Museums \& Galleries on Merseyside.

Kahn,C. 1997. Plato and the Socratic Dialogue: The Philosophical Use of a Literary Form. Cambridge: Cambridge U P.

Kristeva, J 1980. Desire in Language: A Semiotic Approach to Literature and Art. NY: Cambridge UP.

Lenin, V.I. 1939. Imperialism: The Highest Stage of Capitalism: A Popular outline. New York: International Publishers.

Nathan, G. 1953. The Theatre in the Fifties. NewYork: Knopf.

Nicoll, A. 1950. World Drama from Aeschylus to Anouilh. New York: Harcourt Brace.

Ober, J. 2011. "Socrates and democratic Athens: The Story of the trial in its historical and legal contexts." In Cambridge Companion to

Socrates. D. R. Morrison (ed). NY: Cambridge UP: 138-178

Okun M. \& S. Bronz 1973. The Challenge of America. New York: Holt, Rinehart and Winston. 


\section{Heba H. El-ABBADI}

Plato 1925. Phaedrus. In Plato in Twelve Volumes, Vol. 9. Trans. H. N. Fowler. London: Harvard U P.

Plato 1992. The Trial and Death of Socrates: Four Dialogues: Four Dialogues Unabridged. Trans. B. Jowett. New York: Dover Publications.

Puchner, M. 2010. The Drama of Ideas: Platonic Provocations in Theatre and Philosophy. Oxford: Oxford University Press.

Sartori, G 1987. The Theory of Democracy. Revisited. NJ: Chatham House.

Shipley J. T. 1956. Guide to Great Plays. Washington, DC: Public Affairs Press.

Sinfield, A. 2006. "From Bradley to Cultural Materialism," Shakespeare Studies Volume: 34. Retrieved on 1 Jan 2012 from http://www.questia.com: 25+

Skulsky, H. 1958. “Aristotle's Poetics Revisited. Journal of the History of Ideas. 19 (2): 147-60.

Smith, M. 1998. Democracy in a Depression: Britain in the 1920s and 1930s. Cardiff: University of Wales Press.

Steiner, G. 1996. The Death of Tragedy. New Haven: Yale University Press.

Stone, I.F. "I.F. Stone Breaks the Socrates Story." New York Times Magazine, April 8, 1979. Retrieved on 15 Jan 2012 from http://law2.umkc.edu/faculty/projects/ftrials/socrates/ifstoneinter view.html

---. 1988. The Trial of Socrates. Boston: Little, Brown and Company.

Stromberg, R.N. 1996. Democracy: A Short, Analytical History. NY: M.E. Sharpe.

Tees, A. 1980. "Maxwell Anderson's Changing Attitude toward War." North Dakota Quarterly 43(3): 5-11. 
Conflicting Versions of Tragic Socrates

"Text and writing" (écriture)" 2009. In A Glossary of Literary Terms. M.H. Abrams and G.G. Harpham eds. Boston: Wadsworth Cengage Learning.

Vlastos, G. "The Historical Socrates and Athenian Democracy." Political Theory, Vol. 11, No. 4: 495-516. 